\title{
Conscientização: Teoria e prática da libertação - uma introdução ao pensamento de Paulo Freire
}

\author{
Consciousness-raising: theory and practice of liberation- \\ an introduction to the thought of Paulo Freire \\ LÚCIA IACIARA DA Silva \\ William HiRoshi Abeno RONCHI ${ }^{\mathrm{B}}$
}

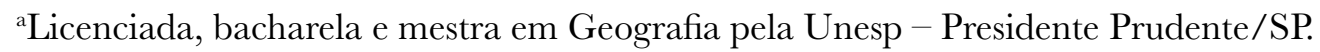

E-mail: luciaiaciara@gmail.com
${ }^{b}$ Licenciado em Geografia pela Unesp - Presidente Prudente/SP e mestrando pelo
Programa de Pós-Graduação da mesma instituição.
E-mail: william.ronchi@unesp.br

\begin{abstract}
Esta resenha crítica analisará o percurso descritivo de Paulo Freire, no propósito de compreensão da ligação entre as partes de seu livro, as quais identificam-se como; "O Homem e sua experiência" na primeira parte, em seguida a "Alfabetização e Consciência" que se refere à base filosófica e seu problema, o processo metodológico e a relação da aplicação para com a leitura e a escrita. Numa terceira parte discorre-se a contextualização da práxis da libertação, na qual é percebida e concebida a crítica de seu pensamento apresentando-se as palavras: opressão, dependência, e o entendimento do relacionamento destes termos associados ao fenômeno no caso através da América Latina. Por fim a compreensão das linhas de transformação a partir da relação pedagógica e intermédio da ação cultural e revolução cultural.
\end{abstract}

Palavras-chave: libertação, ensino, aprendizagem, alfabetização, ciências sociais.

\begin{abstract}
This critical review will analyze the descriptive path of Paulo Freire to understand the correlation between different sections of his book, namely: "Man and his experience" and "Literacy and Consciousness," which refers to the philosophical base and its problem, the methodological process and its relationship with reading and writing. In a third moment, this article contextualizes the praxis of liberation, considering and framing the criticism of Freire's thought through the words oppression and dependence while associating the understanding of these terms within the Latin American scenario. Finally, this work promotes the understanding of the transformation lines catalyzed by the pedagogical relationship, the cultural action, and the cultural Revolution.
\end{abstract}

Keywords: liberation, teaching, learning, literacy, social sciences. 
Freire (1979) expõe momentos de sua trajetória e experiência, mostrando a origem de seu nascimento, que ocorreu oito anos antes da crise econômica que atingiria o mundo todo em 1929. Seu início de vida tem uma ligação com o território e o lugar à medida que o ponto de partida da sua descrição pessoal é a Estrada do Encanamento e o Bairro da Casa Amarela, no Recife (PE), Brasil. Com a morte do pai, autor vivenciou, a experiência da fome, em Jaboatão, para onde se mudara em decorrência dos efeitos da crise econômica, assim compreendendo a fome dos demais

Paulo Freire (1979) reflete sobre sua família ao relatar dificuldades, mas também momentos de felicidade, como jogar bola com os meninos do povo, nadar no rio e, sobretudo, seu pensamento ainda desde garoto para com o futuro, as mazelas sociais e a importância do despertar da consciência para a transformação (dos atos do homem e do futuro).

Com o casamento e três filhos, reconhece a instituição familiar como a ampliação da área dialogal. $\mathrm{O}$ casamento aos 23 anos de idade com Elza M. C. Oliveira, ligada à educação (professora do primário), despertou o interesse maior nas áreas de filosofia do direito, educação, sociologia etc. Licenciado em direito, abandonou o ofício, pois a primeira causa, de uma dívida, mostrou a si a nua condição de injustiça social, com a qual não poderia compactuar.

Assim, seu caminho tomaria outro curso: cumpriu cargo no departamento de educação e cultura do Sesi, depois na Superintendência (1946 a 1954), e fundou o serviço de extensão cultural da Universidade do Recife, sendo seu primeiro diretor.

O golpe de 1964 interrompeu seu projeto alfabetizador de adultos e de promoção da cultura popular. Preso por 70 dias, foi oprimido e tomado como perigoso agitador social, cuja acusação era de "tornar bolchevique o país a partir de seu método".

A pedagogia da liberdade, que estava se disseminando pelo país dentro do governo de João Goulart é interrompida pelo Golpe e por atrozes grupos reacionários, que não pretendiam, de maneira alguma, a partir da conscientização das massas, ver seus privilégios serem questionados, tampouco acabados.

O início da década de 1950 teve forte expressão motivada pelos movimentos sociais. Paulo Freire (1979) destaca o movimento de educação popular e no campo. Isto resultou em movimentos de 85 mil grevistas lutando por direitos, depois 230 mil grevistas, em Pernambuco, criando 1.300 sindicatos.Freire (1979), na simplicidade do ensinar, teve sua primeira experiência exitosa na cidade dos Angicos $(\mathrm{RN})$, com a educação como meio dialógico (linguagem auxiliada por conexões e aproximações entre sílabas e palavras faladas), permitindo expressividade comunicativa e a alfabetização de 300 trabalhadores em 45 dias.

Sobre o exercício da política no Brasil, Freire afirma um problema prático, a ausência de acompanhamento das atividades na escola local - não há uma participação efetiva no cotidiano das pessoas e sim o fechamento em gabinetes, longe da experimentação da pobreza.

Paulo Freire constata a necessidade de uma práxis humana - o conhecimento pelo ato reflexivo, numa indissociabilidade entre a ação de uma pessoa e reflexão sobre o mundo, então como fundamento da conscientização enquanto exercício crítico e, mais que isso, compromisso histórico.

Disso decorre à postura que Freire (1979) destaca sobre o agir: todo exercício crítico da realidade envolve que o indivíduo seja utópico. O educador ser utópico não é sinônimo de algo irrealizável, mas indica a própria práxis humana voltada à mudança, a dupla interdependência do anunciar (humanizar) as transformações sociais e denunciar (a estrutura desumanizante).

Nesse movimento dialético do pensamento de Freire emerge o processo de conscientização. O Brasil carece desta perspectiva, já que via de praxe os políticos se interessarem com o povo como massa de manobra para seus interesses partidários e pessoais.

Disso surge à importância da percepção crítica do concreto (a interpretação da realidade das partes para o todo, do abstrato para o concreto). É a partir disso que nos afirmamos enquanto sujeitos e não como objetos da história, daí a unidade do pensamento de Paulo Freire.

É o que Freire menciona como reconhecimento de realidades que são exteriores ao homem, e a possibilidade dele se engajar como um ser-em-situação.

Para ele, existe uma construção do ontem, do hoje e do amanhã (historicidade e capacidade de discernimento, diga-se tomada de consciência).

Para "Freire", o Homem tem que ser criador de "cultura, que é uma aquisição sistemática da experiência humana" (FREIRE, 1979, p. 21). Portanto, ter vivacidade de sua prática de (re) inventar.

Assim, a família silábica era importante para o autor, pois, a exemplo, na palavra LU-TA, cada parte constitui um encontro: LA-LE-LI-LO-LU e TA-TE-TI-TO-TU, num jogo conjunto de palavras, ele inova na forma de educar, a partir da perspectiva de uma mensagem e comunicação, uma forma diferente de atingir o alfabetizando. 
A noção de consciência no mundo de Freire se dá quando ressalta o valor das pessoas, cada qual com sua atividade, intelectual, braçal, artesanal... o sapateiro, o gari, o professor, sem impor comparativos de superioridade-inferioridade, e sim reconhecimento de igualdade e importância no cotidiano, como peça importante da sociedade. Isso o faz um intelectual digno de valoração.

Por fim, para Freire (1979) a cultura é a inclusão crítica e criadora, a relação natureza-cultura, enquanto consciência no mundo. Sua atitude frente à vida é importante, pois não impõe hierarquias opressivas no processo dialógico, portanto não há sentimento de medo com ele, receio, nem opressão, há educação com cuidado, atenção e qualidade de vida.

\section{REFERÊNCIAS}

FREIRE, P. Conscientização: teoria e prática da libertação - uma introdução ao pensamento de Paulo Freire. São Paulo: Cortez e Moraes, 1979. 